\title{
The Effect of Corporate Tax Governance, Audit Quality and Tax Exposure on Audit Fee for Companies Enlisted in Indonesia Stock Exchange
}

\author{
R. Nelly Nur Apandi, Sidharta Utama, Hilda Rosieta \\ Universitas Pendidikan Indonesia \\ Bandung, Indonesia
}

\begin{abstract}
- an important issue in the audit process is closely related to the amount of fees set out in an audit engagement. One of the determinants of audit fees based on the characteristics of the audited is related to the corporate governance. The purpose of this study is to determine the effect of corporate tax governance on audit fee. This study also aims to look at the effect of audit quality and tax exposure that moderate the relationship between corporate tax governance and audit fee. The sample of this study is the companies enlisted in Indonesia Stock Exchange in 2013 and 2014. The amount of the sample is 115 companies. Data were analyzed by using multiple linear regression analysis. This study shows that the Tax Corporate Governance has a negative effect on audit fee. However, this study is not able to prove that the audit quality and tax exposure moderate the effect of corporate tax governance on audit fee. The implications of this study is that the adoption of good corporate tax governance becomes important in the company's business process because it can provide benefits to companies associated with lower audit fees.
\end{abstract}

Keyword : Corporate Tax Governance, Auditor Quality, Tax Exposure and Audit Fee

\section{THE BACKGROUND OF THE STUDY}

Audit fee is one of auditors' considerations in engaging audited. Nowadays the business side of audit profession is inevitable. This is why lots of people say that business and professionalism are two different sides of the same coin. Audit fee becomes an interesting issue to study because on one side it will affect the business of audit profession and on the other hand will affect the audit quality.

The policy of audit fee in Indonesia is stated in SK/KEP.024/IAPI/VII/2008. The policy reflects the challenge of abnormal audit fee that is faced by the auditors. Some people claim that it may lower audit quality. However, the others say that it is a result of different level of efficiencies conducted in public accounting firms and it doesn't affect audit quality. This divergent views makes it debatable regarding the need of regulations to set the minimum audit fee in Indonesia.

Audit fee is affected by many factors. Using metaregression analysis, [1] maps the previous studies that explain three perspectives to determine audit fee: client attribute, auditor attribute and engagement attribute. Based on auditor perspective, auditors notice the size, complexity, inherent risk, profitability, leverage, internal audit, industry and corporate governance of a company. [1] describe that studies on correlation between corporate governance and audit fee are relatively little. Therefore, it is needed further studies on the effect of both. This is the reason that motivates the writer to conduct further study on corporate governance and audit fee.

The low level of corporate governance reflects a high level of audit risk, so that the auditors will set the audit fee higher [2]. According to [3] the high level of audit risk makes the auditors expand the scope of audit to ensure that collected evidence can be used as a basis for concluding the audit. The company will seek to improve its governance in order to enhance shareholder value [4]. Therefore, the auditors have a role in improving corporate governance through a good quality of audit [5].

Corporate governance is affected by the reporting environment of the company. A high level of fraudulent financial report indicates a low level of corporate governance. One of fraudulent financial reports that becomes the focus of the government is tax fraud. [6] states that potential tax money in Indonesia that was not deposited into the state treasury over twelve years from 2001 to 2012 reached Rp1,760.9 trillion. This undeposited tax money, tax fraud, causes state loss. The state loss resulted by tax fraud is far greater than one resulted by corruption. Based on the data from the Supreme Court decisions over twelve years from 2001 to 2012, the amount of state loss due to corruption reached Rp168.19 trillion. Therefore the implementation of Corporate Tax Governance becomes an important factor to avoid potential state loss.

According to [7] Tax Corporate Governance is a process to guide the company in carrying out tax obligations in accordance with the current tax regulations. As a taxpayer, a company is obliged to count, calculate, pay and report tax payable in accordance with tax regulations. However, in fact, after tax audit, it is found that there are noncompliance taxpayers that fiscus considers that they conduct tax shelter and eventually fiscus issues Decree of Underpayment of Tax (SKPKB). This is why the company with a low level of corporate tax governance doesn't count, calculate, pay and report its tax payable in accordance with the tax regulations. 
The auditors of the low corporate tax governance will charge the company with a high audit fee, because the financial reporting tax risk will increase as well. The high risk of audit leads to a high audit fee, because the auditors need to work harder to reduce the risk of detection [2]. Study on corporate tax governance is a new issue and study that specifically relates it to audit fee has not been conducted in the capital market of Indonesia. The previous study conducted by [8] just relates the fee paid to the auditors for tax service to the level of Corporate Governance. That study shows that tax service fee is affected by corporate governance. Meanwhile another study conducted by [9] finds that tax service fee doesn't affect GAAP ETR and Cash ETR that reflects tax aggressive planning.

The discrepancy of those previous studies may be caused by, First; different audit qualities. A high-quality auditor certainly will notice audit risk deeper than the low-quality one. The high-quality audits are attached to the BIG4 public accounting firms (KAP BIG4). [10] [11] [12] and [13] state that KAP BIG4 have a higher risk of lawsuits than KAP Non BIG4 that have low-quality audits. That's why the effect of corporate tax governance on audit fee is rather different. It depends on audit quality of the auditors. The high-quality auditors have a deeper consideration on corporate tax governance that it affects their audit fee. Second; the discrepancy of those previous studies may be caused by tax exposure, possible risks of high tax payable in the future. A company with a high risk of tax payable will certainly be the focus of attention for the auditors. On the one hand, a good corporate tax governance may lead to a low audit risk. But on the other hand the potential tax payable in the future may in fact lead to the increase of audit risk. As stated by [14] that a company with a high corporate social responsibility is considered to be able to reduce the aggressiveness in lowering its tax payable.

Based on the above description, this study aims to see 1) the effect of corporate tax governance on audit fee; 2) the effect of corporate tax governance on audit fee moderated by audit quality and 3) the effect of corporate tax governance on audit fee moderated by tax exposure. The results show that corporate tax governance has a negative effect on audit fee. However, this study is not able to prove that a good audit quality and tax exposure moderate the effect of corporate tax governance on audit fee. This study contributes to specifically see the effect of corporate governance on audit fee. This study also gives a contribution to the different results of previous studies on corporate governance and tax service fee. This discrepancy may be caused by two things, i.e. audit quality and tax exposure. Therefore this study specifically relates those two things to corporate tax governance and audit fee.

\section{LITERATURE REVIEW AND HYPOTHESIS DEVELOPMENT}

\section{A. Literature Review}

1) Corporate Tax Governance, Tax Planning and Tax Shelter.

Good corporate governance becomes the focus of all stakeholders, including the regulators. The government as the regulator has many interests in companies, such as taxation aspect. State revenue from taxes are the main source of state government fundings. Good Corporate Governance is a process and structure used by the company to improve its performance and accountability in order to create long-term values for the shareholders while keep on considering the interests of other stakeholders, based on the laws and ethical values [15]. Whereas Corporate Tax Governance is corporate governance that is related to taxation. [7] defines Corporate Tax Governance as a process to direct the company in fulfilling its tax obligations based on the current tax regulations. Based on Indonesia tax regulations, a company is obliged to count, calculate, pay and report its tax payable. Therefore the company with a good corporate tax governance will count, calculate, pay and report its tax payable in accordance with the current tax regulations.

To ensure that the reported taxes comply the tax regulations, fiscus regularly conducts tax assessments, [16]The results of tax assessments are the issuance of tax underpayment assessment letter (SKPKB), tax overpayment assessment letter (SKPLB) and nil tax assessment letter (SKPKN). For many companies, tax payment is considered as something to frequently avoid. [17] states that a company seeks to conduct tax avoidance through a good tax planning. According to Zain (2007) tax planning is an activity associated with the potential tax consequences by controlling every transaction that cause tax consequences. Tax planning that aims to obtain tax saving is conducted by mathematical tax avoidance in compliance with tax regulations.

However, an aggressive tax planning may cause a company to commit tax evasion that it will eventually get penalties (tax shelter).[18] describes that tax shelter is an activity of a company in the context of avoidance and violation identified by fiscus (tax authorities).A study conducted by [19] explains that aggressive tax planning affects tax shelter. The penalized company may indicate that it has a weak internal control of taxation. [20] states that internal control is a determining factor of tax aggressive planning. Therefore, the weak internal control of tax obligations by the board of directors and board of commissioners may cause the company to get penalized.

\section{2) Audit Fee}

The relationship between auditors and auditee is created through audit engagement. Auditors is in charge of gathering and evaluating evidence to determine the degree of correspondence between criteria and existing information [3]. Whereas auditee is an entity that was or being auditee by auditors. The engagement between auditors and auditee is a unique one. Unlike other professional services, auditors engage auditee through audit fee from the auditee while the results of the audit is indeed used by other stakeholders. Thus, when abnormal audit fee happens, audit fee becomes interesting to study[21][22].

Audit fee is a topic that was firstly studied by [23] Audit fees can be understood from the perspective of supply and demand of services. From the perspective of supply, audit fee is considered as an assessment effort of audit risk. Hence audit fee will be reduced when resource allocation performed by the auditors in the audit process is also reduced [24]. Based on the 
result of the study conducted by [1] that used meta regression analysis on hundreds research articles on audit fee, it is concluded that study on audit fees is based on three attributes: client attribute, auditor attribute and audit engagement. Based on the perspective of client attribute, a factor that affects the amount of tax payable is the level of corporate governance.

The correlation between corporate governance and audit fee may be observed from two perspectives: supply and demand. From supply perspective, [25] state that good corporate governance may lead to low audit risk and eventually lower audit fee. However, from demand perspective, audit fee is higher on companies with a better corporate governance because they prefer to choose audit service with a better-quality audit. Thus this implicates a higher audit fee [5][24]

\section{B. Hypothesis Development}

1) The Effect of Corporate Tax Governance and Audit Fee

The process of directing and controlling company in order to fulfill tax obligations in compliance with the tax regulations is called corporate tax governance. A company with a high level of corporate governance tends to have a good mechanism in managing its tax obligations. However, in fact, tax payment is something generally avoided by taxpayer so that the company will maximally seek to conduct tax avoidance [17]. According to [8], on the one hand the effort of less tax payment becomes something that benefits the shareholders because it reduces the cost of the company. But on the other hand this effort is considered to be unethical because the tax is going to be used by the country for the sakes of public (stakeholders).

In the short term aggressive tax planning may benefit the company. But in the long run this may harm the company because the possibility of lawsuits against the company is getting bigger. Therefore the management, board of directors, board of commissioners and other elements of the company will seek to properly manage its tax obligations. The positive effect of a good tax governance is the reduction of audit fee. According to [2][26][27], a company with a good rate of corporate governance has a negative effect on audit fee.

Auditors focus to reduce asymmetry information that occur between agent and principal, including the state that is the part of company's stakeholders. Tax report set forth in the company's financial statements is part of the scope of audit that has to be assured the suitability of its presentation and the fairness of its assessment. According to [2], a company with a high level of corporate governance is considered by the auditors to have a low audit risk that it may reduce audit fee.

The correlation between high corporate tax governance and low audit fee may be explained as follows: first, a company with a high corporate tax governance may have a sufficient internal control regarding tax mechanism of the company. The good internal control of the company may reduce the scope of substantive test of transaction [28]. When the auditors conduct test of internal control regarding tax aspects and find that the mechanism of the company control regarding tax transaction is sufficient, the auditors will be assured that the internal control may improve the accuracy of the financial statements so that the scope of substantive test of transaction becomes smaller. Thus, the small allocation of time and resources may reduce audit fee.

Second, a company with a good corporate tax governance may have a completed, accurate documentation and company record. According to [29], a company with a good corporate governance may have a good environment of accounting and financial statement that this may lead to a better quality of information. Auditors have the obligation to conduct test of analytical procedure and test of detail balance against tax transaction of the company. In the process of test of analytical procedure, auditors are obliged to compare financial statement of audit year and of a year back [3]. The accurate a-year-back data may help the auditors conduct a more precise assessment to determine whether the auditors need to expand the obtained scope and evidence. While in the test of detail balance, auditors are obliged to recount and trace the relevant account [3]. The complete, accurate and punctual tax data are certainly derived from a good mechanism of tax governance of the company. The easiness of tracing the tax evidence for the auditors may help them to get a sufficient assurance that tax report on financial statement of the company is fairly presented [30]. Thus, this will lead to a lower audit fee.

Third, a company with a good corporate governance regularly identifies the risk of lawsuits and penalties over company actions, including tax transaction. According to [31], the role of internal audit significantly leads to the improvement of corporate governance. The regular identification of tax risk indicates that the company has a good mechanism of prevention and detection of the risk of lawsuits and tax penalty. Regarding risk identification, auditors are obliged to analyze subsequent event and contingency liability [3]. If the mechanism of tax risk identification is conducted regularly, it will ease the auditors to assess the fairness of contingency liability. Thus, this will lead to a lower audit fee.

Based on the description above, it is concluded that the high level of corporate tax governance may reduce the risk of detection and audit, so that it implicates a lower audit fee. Therefore the hypothesis is formulated as follows:

H1 = The Level of Corporate Tax Governance That Has A Negative Effect on Audit Fee.

2) The Effect of Corporate Tax Governance, Audit Quality and Audit Fee

The quality of the information presented to the stakeholders in the financial statements after the audit process depends on audit quality of the auditors. The better the quality, the generated information will be more relevant, reliable, timely and accurate. The auditors with a good audit quality may have the capability of identifying audit risk well [32]. Hence, this level of audit risk becomes the main consideration of auditors in deciding the amount of audit fee they will charge.

Based on the previous study, a good audit quality is often associated with the big four public accounting firms (KAP big four). According to [13], the big four public accounting firms have the capability of assessing the suitability and fairness of 
financial statement better than non-big four public accounting firms. That statement is supported by several reasons:

First, KAP big four pay attention to litigation risk higher than KAP non-big four. The tendency shows that KAP big four may face more risk of lawsuits, because they are identical with Deeper Syndrome Pocket so that they seek to be consistent in maintaining their audit quality. Second, KAP big four tend to be able to reduce asymmetry information better than KAP non-big four. It's all because they have a better capability in assessing the disclosure of financial statement of the client. Hence, the reduction of asymmetry information between the management of the company (agent) and the owner of the company (stakeholder) may eventually reduce the cost of equity capital.Third, KAP big four face more inspections than KAP non-big four. Based on the regulation of Sarbanes-Oxley 2002 PCAOB, KAP big four are generally inspected once a year. Whereas KAP non-big four are inspected once in three years. Fourth, KAP big four has a better capability of accounting and audit than non-big four, because they have a better audit technology and is capable of maintaining the quality of their findings.

These four reasons show that audit quality of big four public accounting firms is considered to be better than one of non-big four. Hence in assessing audit risk, the qualified auditors note the level of corporate tax governance. As a result, the company with a high level of corporate governance will be considered to have a lower audit risk by the auditors. Meanwhile the unqualified auditors note the level of corporate tax governance inaccurately. Thus, a good audit quality may reinforce the negative effect of corporate tax governance on audit fee. Based on the description above, the hypothesis is formulated as follows:

$\mathrm{H}_{2}=$ the Level of Corporate Tax Governance That Has A Negative Effect on Audit Fee That Is Moderated by Audit Quality

\section{3) The Effect of Corporate Tax Governance, Audit Quality} and Audit Fee

The transactions in a company as a taxpayer entity cannot be separated from its tax obligation with regard to income tax, value added tax (PPN) and value added tax on luxury goods (PPN-BM). Therefore every transaction that may cause the risk of tax payable in the future (tax exposure) will be the main focus of the auditors in conducting audit. A company with a high tax burden generally tends to commit tax avoidance. As stated by [17], a multinational company with a high profit has a higher tendency to commit tax avoidance than a small company.

An experimental study conducted by [33] proves that random tax assessments conducted by fiscus cause the highincome taxpayers to calculate first the risk of assessment. If the risk is small, the high-income taxpayers will report their tax payable not in compliance with the regulations. On the contrary, if the risk is big, the high-income taxpayers will do the opposite. At the same time the low-income taxpayers will not calculate the risk of fiscus assessments. Thus they tend to report their tax payable in compliance with the regulations.
The high level of corporate tax governance has a negative effect on audit fee that is moderated by low tax exposure. When the tax burden is high as a result of a high taxable income, it certainly will affect the scope of audit. A study conducted by [34] states that the profitability of a company affects audit fee. The higher profitability, the more audit fee. Whereas a company with a high litigation risk has a positive effect on audit fee [35]. So as when the company experiences a high tax payable. For the auditors, this is one of audit risks because the risk of the company experiences financial difficulties will be higher.

Based on the description above, it is concluded that the low tax exposure of a company will reinforce the effect between high corporate tax governance and low audit fee, because audit considers the risk of tax payable in the future is small. Therefore the hypothesis is formulated as follows:

H3 = The Level of Corporate Tax Governance That Has A Negative Effect on Audit Fee That Is Moderated by Low Tax Exposure

\section{RESEARCH METHOD}

\section{A. Research Model}

This study used quantitative model with a basis model of [23] adopted by the study of [21][26]. Regression model in this study consists of three models. To answer the first hypothesis, the research model is as follows:

$$
\begin{gathered}
\text { LNFEE }=\beta_{0}+\beta_{1} \text { CTG }+\beta_{2} \text { TobinQ }+ \\
\beta_{3} \text { BIG }+\beta_{4} \text { LnAssets }+\beta_{5} \text { Loss }+ \\
\beta_{6} \text { Recint }+\beta_{7} \text { Invint }+\beta_{8} \text { Subrt }+\varepsilon
\end{gathered}
$$

Whereas to answer the second hypothesis, regression model used is as follows:

$$
\begin{gathered}
\text { LNFEE }=\beta_{0}+\beta_{1} \text { CTG }+\beta_{2} \text { BIG } 4+\beta_{3} \text { CTG* } \\
\text { BIG4 }+\beta_{4} \text { Tobin } Q+\beta_{5} \text { LnAssets }+\beta_{6} \text { Loss }+ \\
\beta_{7} \text { Recint }+\beta_{8} \text { Invint }+\beta_{9} \text { Subrt }+\varepsilon
\end{gathered}
$$

The third research model is used to answer the third hypothesis that the equation model is as follows:

$$
\begin{aligned}
& \quad \text { LNFEE }= \\
& \beta_{0}+\beta_{1} \text { CTG }+\beta_{2} \text { Tax Exsposure }+\beta_{3} \text { CTG } * \\
& \text { TaxExsposure }+\beta_{4} \text { BIG4 }+\beta_{5} \text { Tobin } Q+ \\
& \beta_{6} \text { LnAssets }+\beta_{7} \text { Loss }+\beta_{8} \text { Recint }+ \\
& \beta_{9} \text { Invint }+\beta_{10} \text { Subrt }+\varepsilon
\end{aligned}
$$

\section{Description:}

LNFEE = Natural log of audit fee

CTG $=1$ if the company earns SKPKB in the last 2 years of reporting period and 0 if it does not earn SKPKB. 
TobinQ = Market value equity plus book value of liabilities divided by book value of assets

BIG4 = 1 if the company is audited by KAP BIG4 and 0 if it is audited by KAP NONBIG4

Tax Exposure $=$ the amount of tax payable divided by total assets

LnAsset $=$ Natural log of total assets

Loss $=1$ if the company experiences a loss during the reporting period

Recint $=$ Account receivable divided by total assets

Invint = Inventory divided by total assets

Subrt $=$ Number of consolidated subsidiaries

\section{B. Population, Sample and the Technique of Data Analysis}

The sample of the study is companies listed in Indonesia Stock Exchange in 2013 and 2014. This study doesn't include companies of financial and banking because they have a specific characteristic of financial statement. Based on data derived from the website of Indonesia Stock Exchange, it is found that the number of listed companies is 502. The observation is conducted for two years because the disclosure of audit fee is in 2012 and is effective in 2013. The number of companies that disclose audit fee in 2013 is 26, while in 2008 is 173 .

Data on components in the financial statements derived from the data stream at the Centre for Economics and Business Data (PDEB, Pusat Data Ekonomi dan Bisnis). Whereas data of audit fee and subsidiary entities derived from companies annual reports. The technique of data analysis is OLS (Ordinary Least Square), where the requirements of the usage must meet classic assumption test in order to produce a linear unbiased estimator with minimum variance (Best Linear Unbiased Estimator = BLUE) [36]. The tests to be done are 1) Normality Test using Jarque-Bera test, 2) Heteroscedasticity test using the breusch pagan godfrey test, 3) Multicolinearity test by calculating the value of Tolerante and Variante Inflation Factor (TOL and VIF)

Furthermore, after the BLUE test, the hypothesis test was done with step of: 1) Establishing the null hypothesis and the alternative hypothesis; 2) Establishing a significance level of $\rho$ $=0.05$ and this study used two-party test; 3) Establishing criteria for the decision, if tcount $<\mathrm{t}$ table; hence Ho is accepted and $\mathrm{Ha}$ is rejected, and if tcount $>\mathrm{t}$ table; then Ho is rejected and $\mathrm{Ha}$ is accepted.

\section{DISCUSSIONS}

\section{A. Descriptive Statistics}

This study aims to find out the effect of corporate tax governance on audit fee. This study also aims to see the effect of corporate tax governance on audit fee that is moderated by audit quality. Finally this study aims to see the effect of corporate tax governance on audit fee that is moderated by tax exposure. Here is the results of descriptive statistics of each variable:
TABLE I. DESCRIPTIVE STATISTICS

\begin{tabular}{|c|c|c|c|c|c|}
\hline Variabel & $\mathbf{n}$ & Min & Max & Mean & $\begin{array}{l}\text { Standar } \\
\text { Deviasi }\end{array}$ \\
\hline \multicolumn{6}{|l|}{$\begin{array}{l}\text { Panel A } \\
\text { Dependen } \\
\text { dan } \\
\text { Independen } \\
\end{array}$} \\
\hline LNFEE & 115 & 14.0779 & 24.3068 & 20.3254 & 1.40422 \\
\hline CTG & 115 & p & 1 & 0.3739 & p.48596 \\
\hline \multicolumn{6}{|l|}{$\begin{array}{l}\text { Panel B } \\
\text { Moderating }\end{array}$} \\
\hline BIG4 & 115 & p & 1 & 0.487 & D.50202 \\
\hline \begin{tabular}{|l} 
Tax \\
Exsposure \\
\end{tabular} & 115 & p.0001 & p.0859 & 0.009148 & D.011221 \\
\hline \multicolumn{6}{|l|}{$\begin{array}{l}\text { Panel B } \\
\text { Control }\end{array}$} \\
\hline TobinQ & 115 & p.3366 & 43.5639 & 1.96615 & 4.234128 \\
\hline InAsset & 115 & 17.6614 & 26.1749 & 21.69125 & 1.649518 \\
\hline Loss & 115 & p & 1 & 0.1739 & 0.38069 \\
\hline Recint & 115 & p.0013 & b.6919 & 0.159515 & b.136607 \\
\hline Invint & 115 & b.0001 & b.6101 & b.163841 & b.152627 \\
\hline Subrt & 115 & p & 120 & 10.2783 & 16.21108 \\
\hline
\end{tabular}

Description: LNFEE=Natural $\log$ of audit fee; $\mathrm{CTG}=1$ if the company earns SKPKB in the last 2 years of reporting period and 0 if it does not earn SKPKB.; TobinQ= Market value equity plus book value of liabilities divided by book value of assets; BIG4 $=1$ if the company is audited by KAP BIG4 and 0 if it is audited by KAP NONBIG4; Tax Exposure $=$ the amount of tax payable divided by total assets; LnAsset $=$ Natural $\log$ of total assets; Loss $=1$ if the company experiences a loss during the reporting period; Recint=Account receivable divided by total assets; Invint= Inventory divided by total assets;Subrt= Number of consolidated subsidiaries

Based on descriptive statistics data in Table 1 Panel A, the mean of LNFEE and CTG respectively are 20.3254 and 0.3739 . Audit fee that exceeded the mean is of the big four auditors. The interesting fact of Corporate Tax Governance in this study is that 43 companies or $37 \%$ of population earn Decree of Underpayment of Tax (SKPKB).

Based on the results of descriptive statistics of moderating variable in Table 1 Panel $\mathrm{B}$, the mean of BIG4 is 0.487 . While the mean of Tax Exposure variable is 0.009148.The interesting fact of Table 1 Panel $B$ is that the number of companies engaged with KAP big4 is almost a half of population, i.e. $48 \%$. The remaining 52\% made audit engagement with non-big four KAP. Total number of KAP listed in the Indonesia Stock Exchange is 61 KAP. 52\% of non-big four engagements are contested by 57 KAP (61 KAP minus 4 KAP). This shows that the market share of KAP big 4 is very big in the capital market of Indonesia. 


\section{Asuners PRESS}

The mean of each control variable in Table 1 Panel $\mathrm{C}$ is as follows: TobinQ 1.96615; LnAsset 21.69125; Loss 0.1739; Recint 0.159515; Inventory 0.163841 and Subrt 10.2783. Based on data in Table 1 Panel $\mathrm{C}$, it is found that the sample companies during the period of observation averagely earned positive profit. This is linear with the good value of TobinQ of the sample companies. Furthermore, after conducting descriptive statistical analysis, the correlation test between each variable was conducted as described in the following table:

TABLE II. PEARSON CORRELATION MATRIX

\begin{tabular}{|c|c|c|c|c|c|c|c|c|c|}
\hline Variable & 1 & 2 & 3 & 4 & 5 & 6 & 7 & 8 & 9 \\
\hline LNFEE & & & & & & & & & \\
\hline CTG & $=$ & & & & & & & & \\
\hline BIG4 & $3.341465^{5}$ & $\begin{array}{l}. .21095 \\
5^{*}\end{array}$ & & & & & & & \\
\hline $\begin{array}{l}\text { Tax } \\
\text { Exsposure }\end{array}$ & $\begin{array}{l}3.66770 \\
4\end{array}$ & $\begin{array}{l}.599484 \\
3^{*}\end{array}$ & 5.24563 & & & & & & \\
\hline TobinQ & $0^{0.00230}$ & b.00604 & 0.00249 & $\begin{array}{l}0.00041 \\
1 * *\end{array}$ & & & & & \\
\hline InAsset & $5.533233^{*}$ & 0.081733 & $\begin{array}{l}0.10986 \\
2 * * *\end{array}$ & $\begin{array}{l}0.00132 \\
\beta^{* * *} \\
\end{array}$ & $\begin{array}{l}0.22237 \\
4\end{array}$ & & & & \\
\hline Loss & $2^{*}$ & 0.210526 & 0.10526 & 0.00223 & $\begin{array}{l}1.17132 \\
3\end{array}$ & $\begin{array}{l}0.10258 \\
3\end{array}$ & & & \\
\hline Recint & $3^{1.30528}$ & $\begin{array}{l}6.09809 \\
5 \\
\end{array}$ & $\begin{array}{l}0.36858 \\
4\end{array}$ & 0.00725 & 2.42036 & $\begin{array}{l}3.10299 \\
1 * * *\end{array}$ & 0.04795 & & \\
\hline Invint & 1.633225 & $990443^{* 4}$ & & & & $\begin{array}{l}4.73641 \\
5^{* * * *}\end{array}$ & $\begin{array}{l}0.47859 \\
2^{* * *} \\
\end{array}$ & $\begin{array}{l}0.10554 \\
80\end{array}$ & \\
\hline Subrt & $0.028276^{*}$ & . & $\begin{array}{l}0.00625 \\
b^{* *}\end{array}$ & $\begin{array}{l}0.57 \mathrm{E}- \\
05\end{array}$ & $\begin{array}{l}0.0050 \\
1\end{array}$ & $\begin{array}{l}0.04931 \\
4\end{array}$ & b.00272 & $\begin{array}{l}0.00206 \\
6^{* * * *}\end{array}$ & 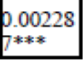 \\
\hline
\end{tabular}

Description: LNFEE=Natural $\log$ of audit fee; $\mathrm{CTG}=1$ if the company earns SKPKB in the last 2 years of reporting period and 0 if it does not earn SKPKB.; TobinQ= Market value equity plus book value of liabilities divided by book value of assets; BIG4 $=1$ if the company is audited by KAP BIG4 and 0 if it is audited by KAP NONBIG4; Tax Exposure $=$ the amount of tax payable divided by total assets; LnAsset $=$ Natural log of total assets; Loss $=1$ if the company experiences a loss during the reporting period; Recint $=$ Account receivable divided by total assets; Invint= Inventory divided by total assets;Subrt= Number of consolidated subsidiaries

$* * * *=1 \%, * *=5 \%$.* $=10 \%$

Table 2 shows the correlation coefficients between CTG, BIG4, Tax Exposure, TobinQ, LnAsser, Loss, Recint, Invint, Indust, Subrt and LNFEE variables. The highest correlation coefficient is $1.341465^{* * *}$, between BIG4 and LNFEE. While the lowest correlation coefficient is $-4.736416^{* * *}$, between Inventr and LnAsset. The correlation coefficient between Tax Exposure and LNFEE in fact shows an insignificant result. It is the same with the correlation between TobinQ and LNFEE as well as Recint and LNFEE. Different correlations between each variable will indicate the most powerful and the weakest predisposition factors to explain audit fee.

\section{B. The Effect of Corporate Tax Governance on Audit Fee}

To answer the first problem identification, an analysis was conducted on the regression equation (1). Based on this, it is obtained the following regression results:

\begin{tabular}{|c|c|c|c|}
\hline Variabel & (Coefficients) & (1) & (2) \\
\hline ntercept & $\beta 0$ & & \\
\hline CTG & $\beta 1$ & $1.012128 * * *$ & $0.509302 * *$ \\
\hline $\begin{array}{l}\text { Variabel } \\
\text { Control }\end{array}$ & & & \\
\hline TobinQ & $\beta 2$ & & 0.012408 \\
\hline BIG4 & $\beta 3$ & & $0.676281 * * *$ \\
\hline LnAsset & $\beta 4$ & & $0.496082 * * *$ \\
\hline Loss & 35 & & $-0.485862 *$ \\
\hline Recint & $\beta 6$ & & 0.146379 \\
\hline Invint & 37 & & 1.129458 \\
\hline Subrt & $\beta 8$ & & -0.003714 \\
\hline
\end{tabular}

Description: LNFEE=Natural log of audit fee; $\mathrm{CTG}=1$ if the company earns SKPKB in the last 2 years of reporting period and 0 if it does not earn SKPKB.; TobinQ= Market value equity plus book value of liabilities divided by book value of assets; BIG4 =1 if the company is audited by KAP BIG4 and 0 if it is audited by KAP NONBIG4; Tax Exposure $=$ the amount of tax payable divided by total assets; LnAsset $=$ Natural $\log$ of total assets; Loss $=1$ if the company experiences a loss during the reporting period; Recint $=$ Account receivable divided by total assets; Invint= Inventory divided by total assets;Subrt $=$ Number of consolidated subsidiaries

$$
* * * *=1 \%, * *=5 \% . *=10 \%
$$

Based on Table 3, it is found that CTG has a significant negative impact on audit fee. It is seen from the values of coefficient and prob that is less than 0.05 , i.e. respectively 1.012128 (0.001). Positive coefficient means negative effect because dummy variable of CTG is 1 if the company earns tax underpayment assessment letter and 0 if otherwise. The result of regression indicates that the higher corporate tax governance, the lower audit fee. While from the second regression that used control variable, the obtained result is similar with the first that corporate governance has a significant negative effect on audit fee at significance level of $5 \%$ and coefficient of 0.509302 . The result of control variable doesn't indicate that all control variable has a significant effect on audit fee. BIG4, LnAsset and Loss are the variables that has a significant effect, with the values of coefficient and prob respectively are as follows: BIG4 is 0.676281(0.001); LnAsset is 0.496082(0.0001) and Loss is -0.485862(0.058). The effect of BIG4 on audit fee is a significant positive. This indicates that most companies that use BIG4 service spend a high audit fee. Similarly, the effect of LnAsset on audit fee is a significant positive. This indicates that the higher company 
assets, the higher audit fee. Meanwhile the effect of Loss on audit fee is a significant negative. This indicates that most companies that experience a loss during observation period spend a high audit fee.

This result of study is in accordance with the previous one conducted by [2] regarding the correlation of corporate governance and audit fee that states that a high corporate governance may reduce audit fee charged to the company. This study is also supported by one conducted by [37] that describes the perception of auditors that low audit risk on family business leads to low audit fee and vice versa. This study is also in accordance with one conducted by [8] that shows specific correlation of tax consulting service fee. The result shows that tax service fee is affected by corporate governance.

The proving of the first hypothesis indicates that good corporate tax governance is taken into the auditor's consideration to reduce test of transaction regarding taxation aspects. As stated by [28], good internal control of the company may reduce the scope of substantive test of transaction. Good corporate tax governance may provide reasonable assurance that tax report is in compliance with the standard of PSAK 46 financial accounting and presented in fair values for material things. Besides, good corporate governance may also provide reasonable assurance on the likelihood of contingent liabilities over tax transactions that it reduce audit risk. Based on the description above, good corporate governance may implicate on the reduction of audit fee.

\section{The Effect of Corporate Tax Governance on Audit Fee Supported by Audit Quality}

To answer the second identified problem the writer analyzed regression model (2). Based on this, it is obtained the following regression results:

TABLE IV. RESUlts OF REgRESSION MODEl 2 CORPORATE TAX GOVERNANCE, AUDIT QUALITY AND AUDIT FEE

\begin{tabular}{|l|l|l|l|}
\hline \multicolumn{1}{|c|}{ Variabel } & (Coefficients) & (1) & (2) \\
\hline Intercept & $\beta 0$ & & \\
\hline CTG & $\beta 1$ & $0.825186^{* *}$ & $0.520356^{*}$ \\
\hline BIG4 & $\beta 2$ & $1.23782^{* * *}$ & $0.683316^{* *}$ \\
\hline CTG*BIG4 & $\beta 3$ & 0.146084 & 0.019843 \\
\hline & & & \\
\hline Variabel Control & & & \\
\hline Tobin Q & $\beta 4$ & & 0.012452 \\
\hline LnAsset & 35 & & $0.495616^{* * *}$ \\
\hline Loss & $\beta 6$ & & $0.488^{*}$ \\
\hline Recint & $\beta 7$ & & 0.141421 \\
\hline Invint & 38 & & 1.132802 \\
\hline Subrt & 39 & & 0.003653 \\
\hline
\end{tabular}

Description: LNFEE=Natural $\log$ of audit fee; $\mathrm{CTG}=1$ if the company earns SKPKB in the last 2 years of reporting period and 0 if it does not earn SKPKB.; TobinQ= Market value equity plus book value of liabilities divided by book value of assets; BIG4 $=1$ if the company is audited by KAP BIG4 and 0 if it is audited by KAP NONBIG4; Tax Exposure $=$ the amount of tax payable divided by total assets; LnAsset $=$ Natural log of total assets; Loss $=1$ if the company experiences a loss during the reporting period; Recint $=$ Account receivable divided by total assets; Invint $=$ Inventory divided by total assets;Subrt $=$ Number of consolidated subsidiaries

$$
* * * *=1 \%, * *=5 \% \text {.* }=10 \%
$$

Based on Table 4, it is found that CTG*BIG4 doesn't have a significant negative effect on audit fee through moderating variable of audit quality. It is seen from the values of coefficient and prob that is more than 0.05 . The result of this regression indicates that audit quality is not able to reinforce the correlation between the heighten of corporate tax governance and the lower of audit fee. While from the second regression that used control variable, the obtained result is similar with the first that corporate governance doesn't have a significant negative effect on audit fee at significance level of $5 \%$ and coefficient of 0.509302 . The result of control variable doesn't indicate that all control variable has a significant effect on audit fee. LnAsset and Loss are the only variables that has a significant effect, with the values of coefficient and prob respectively are as follows: LnAsset is $0.495616(0.0001)$ and Loss is $-0.488(0.06)$. The effect of LnAsset on audit fee shows a significant positive. This indicates that the higher company assets, the higher audit fee. Meanwhile the effect of Loss on audit fee is a significant negative. This indicates that most companies that experience a loss during observation period spend a high audit fee.

The result of this study is not in accordance with the argument of the previous study conducted by [13] that states that KAP BIG4 is a KAP that has a higher quality than KAP NON NIG4. This study is also not in accordance with one conducted by [32] that states that a high-quality auditor is able conduct risk assessment better than the low-quality one. The unproven second hypothesis indicates that a good-quality audit in Indonesia is not always attached to KAP BIG4 because the other second tier KAP are considered to have a better-quality audit. It is proven in the first regression that CTG is significant of $0.825186^{* *}$ and in the second regression that CTG is also significant of $0.520356^{*}$. However, when it is moderated by audit quality, the results become insignificant.

\section{The Effect of Corporate Tax Governance on Audit Fee Supported by Low Tax Exposure}

To answer the third identified problem the writer analyzed regression (3). Based on Table 5, it is found that low tax exposure doesn't intensify the effect of corporate tax governance on audit fee that is proved by the value of prob of more than 0.05 . Meanwhile corporate tax governance has a significant effect on audit fee with the value of coefficient and significance of $1.1333 * * *$. In the second regression, control variable is included. The result of the study indicates the same 
that low tax exposure doesn't intensify the effect of corporate tax governance on audit fee. Meanwhile corporate tax governance has a significant effect on audit fee with the value of coefficient and significance of $0.494673 * * *$.

The result of control variable doesn't indicate that all control variable has a significant effect on audit fee. BIG4 and LnAsset are the only variables that has a significant effect, with the values of coefficient and prob respectively are as follows: BIG 4 is 0.677018 (0.0001) and LnAsset is 0.496302 (0.0001). The effect of $\mathrm{xxx}$ on audit fee is a significant positive. The effect of BIG4 on audit fee is a significant positive. This indicates that most companies that use BIG4 service spend a high audit fee. Similarly, the effect of LnAsset on audit fee is a significant positive. This indicates that the higher company assets, the higher audit fee.

TABLE V. RESUlTS OF REGRESSION MODEL 3CORPORATE TAX GovernanCE, TAX EXPOSURE AND AUDIT FEE

\begin{tabular}{|l|c|l|l|}
\hline \multicolumn{1}{|c|}{ Variabel } & (Coefficients) & \multicolumn{1}{c|}{ (1) } & \multicolumn{1}{c|}{ (2) } \\
\hline Intercept & $\beta 0$ & & \\
\hline CTG & $\beta 1$ & $1.1333 * * *$ & $0.494673 * * *$ \\
\hline Tax Exsposure & $\beta 2$ & 10.62671 & -6.205341 \\
\hline CTG*Tax Exsposure & $\beta 3$ & -14.05432 & 1.586474 \\
\hline & & & \\
\hline Variabel Control & & & \\
\hline BIG4 & $\beta 4$ & & $0.677018 * * *$ \\
\hline Tobin Q & $\beta 5$ & & 0.012892 \\
\hline LnAsset & $\beta 6$ & & $0.496302 * * *$ \\
\hline Loss & $\beta 7$ & & -0.487945 \\
\hline Recint & $\beta 8$ & & 0.145594 \\
\hline Invint & $\beta 9$ & & 1.124786 \\
\hline Subrt & $\beta 10$ & & -0.003733 \\
\hline
\end{tabular}

Description: LNFEE=Natural log of audit fee; $\mathrm{CTG}=1$ if the company earns SKPKB in the last 2 years of reporting period and 0 if it does not earn SKPKB.; Tobin $Q=$ Market value equity plus book value of liabilities divided by book value of assets; BIG4 $=1$ if the company is audited by KAP BIG4 and 0 if it is audited by KAP NONBIG4; Tax Exposure $=$ the amount of tax payable divided by total assets; LnAsset $=$ Natural $\log$ of total assets; Loss $=1$ if the company experiences a loss during the reporting period; Recint $=$ Account receivable divided by total assets; Invint= Inventory divided by total assets;Subrt= Number of consolidated subsidiaries

$$
* * * *=1 \%, * *=5 \% . *=10 \%
$$

This study doesn't support the result of previous study conducted by [35] that states that litigation risk positively affects audit fee. This study is unable to prove that low tax exposure is considered by the auditors as a low audit risk. Hence low tax exposure is considered to be unable to reinforce the effect of corporate tax governance on audit fee. The unproven third hypothesis may be caused by the size of tax burden that has not been a main focus of auditors in assessing risk as long as the company has a good financial power.

\section{E. Robustness Test}

This study conducts a robustness test by using indicator variable of audit quality, KAP BIG5, by adding one public accounting firm is considered to have a good audit quality in Indonesia. The choice of this KAP is that this KAP is quite dominant in the second tier audit market share. The result describe( Not tabulated) CTG and BIG5 significantly affect audit fee both in regression (1) and regression (2). The coefficient of CTG and BIG5 respectively are $0.825959 * * *$ and $1.040395 * * *$. While in regression (2) that includes control variable, the coefficient of CTG and BIG5 respectively are $0.533175^{* *}$ and $0.59016^{* * *}$. This indicates that for Indonesia market share the second tier KAP that have a quite significant number of clients is proven to have a good audit quality.

\section{CONCLUSIONS, IMPLICATIONS AND LIMITATIONS OF THE STUDY}

\section{A. Conclusion}

Based on the description above, the effects of corporate tax governance, audit quality and tax exposure on audit fee are as follows:

- Corporate tax governance has a negative effect on audit fee. This indicates that a high rate of corporate tax governance leads to a low audit fee.

- This study is unable to prove that the negative effect of corporate tax governance on audit fee is moderated by audit quality. This proves that public accounting firms that have a good- quality audit which is proxied by the reputation of the auditor BIG4, have not fully used its audit risk assessment in determining audit fee, especially one related to taxation risk.

- This study is also unable to prove that the negative effect of corporate tax governance on audit fee is moderated by low tax exposure. This indicates that the auditors have not thoroughly considered the amount of tax payable because they assume that as long as the company has a good rate of profitability, the possibility of failed payments of tax payable is relatively small.

\section{B. Implications}

Based on the result of this study, it is found that the number of companies that disclose the information of audit fee is relatively small. This indicates that the rate of audit fee disclosure in Indonesia is relatively small. Therefore the regulators of Indonesia are expected to be able to encourage transparency improvement on annual report with a good reporting mechanism. This study also shows that the implementation of audit risk assessment related to tax risk in Indonesia is still low so that either audit quality or tax exposure is not able to reinforce the effect of corporate tax governance variable on audit fee. This study is expected to be able to provide a description for auditors of Indonesia to improve their capability on audit risk assessment in all aspects that contain risks derived from client companies, including tax aspect. 


\section{Limitations of the Study}

The use of corporate tax governance indicator proxied by the receipt of Tax Underpayment Assessment Letter has a weakness in measurement, especially if it's applied to the country with a low reinforcement of law. Based on the previous studies, Indonesia is categorized as a country with a low reinforcement of law. Therefore the proxy is not considered to be less strong to measure the level of corporate tax governance. For the next researcher, a more-accurate proxy may be used to measure corporate tax governance.

Another weakness of this study is that the amount of data is relatively small. Therefore the next researcher is expected to use cross-country analysis that specifically compares different industries in countries with different characteristics.

\section{REFERENCES}

[1] Hay, D. et al (2006). Audit Fees : A Meta-Analysis of The Effect of Supply and Demand Attributes. Contemporary Accounting Research Vol 23,Issue 1 Pages 141-191

[2] Khan et al (2015). Audit Fees, Auditor Choice and Stakehoder Influence : Evidence From a Family Firm Dominated Economy. The British Accounting Review pp 1-17

[3] Arens et al (2014) Auditing and Assurance Services an Integrated Approach. Pearson

[4] Attig et al (2008) Multiple Large Shareholders, Control Contests and Implied Cost Of Equity. Journal of Corporate Finance 14 pp721-737

[5] Fan \& Wong (2005). Do External Auditors Perform a Corporate Governance Role in Emerging Markets? Evidence From East Asia. Journal of Accounting Research Vol 43 No 1

[6] Amin Laili (2014). Artikel dalam web pajak.go id

[7] Blerck (2011). Blog Blerck

[8] Huseynov \& Klamn (2012), Tax avoidance, tax management and corporate social responsibility, , Journal of Corporate Finance, 18 (2012), 804-827

[9] Armstrong et al (2011) The Incentives For Tax Planning. Journal Accounting of Economic 53 pp 391441

[10] Becker et al (1998). The effect of audit quality on earnings management. Contemporary Accounting Research, 15(1),1-24.

[11] Kim et al (2003)“The Joint Effect of Investor Protection and Big 4 Audits on Earning Quality Around The World" Contemporary Accounting Research, 25 (1),157-191

[12] Francis, J. (2004). What do we know about audit quality?. The British Accounting Review 36 (2004) 345-368

[13] Lee \& Park (2013). Subjectivity in fair value estimates, audit quality and in formativeness of other comprehensive income. Advance in Accounting, incorporating advances in international accounting 29 (2013) 218-231

[14] Shafer \& Simmons (2008) Social Responsibility, Machiavellianism and Tax Avoidance. Accounting Auditing and Accountability Journal Vol 21 No 5

[15] Sutedi (2011) Good Corporate Governance. Jakarta.Sinar Grafika

[16] Resmi (2011) Perpajakan Teori dan Kasus. Edisi 6 Jilid 1. Jakarta. Salemba Empat
[17] Taylor \& Richardon (2012) International Corporate Tax Avoidance Practices: Evidence from Australian Firms. The International Journal of Accounting, 47 (2012) 469-496.

[18] Hanlon \& Heizman (2010) A Review of Tax Research.Journal Accounting and Economic 50 pp127-178

[19] Frank et al (2009) Tax Reporting Aggressiveness and Its Relation To Aggressive Financial Reporting. The Accounting Review Vol 84 No 2 ppp 467-496

[20] Bauer (2011) Internal Control Quality as an Explanotary Factor of Tax Avoidance. Working Paper Schoo of Accounting and Finance University of Waterloo

[21] Rusmanto \& Woworuntu (2014). Factor Influencing Fee Indonesia Publicly Listed Company Applying GCG. Procedia Social Behavioral Sciences 172 pp 63-67

[22] Xie \& Ye (2010). Abnormal Audit Fees And Audit Opinion-Futher Evidence From China's Capital Market

[23] Simunic (1980) The Pricing of Audit Service : Theory and Evidence. J.Account.Res 18(1) pp 161-190

[24] S.Johl et al (2012). Audit Committee and CEO Ethnicity and Audit Fees Some Malaysian Evidence. The International Journal of Accounting 47 pp 302-332

[25] Gul, F.A., Tsui, J.S.L., 2001. Free cash flow, debt monitoring, and audit pricing: further evidence on the role of director equity ownership.Auditing: A Journal of Practice and Theory 20, 72-84.

[26] Wu (2012) Corporate Governance and Audit Fees : Evidence From Companies Listed on The Shanghai Stock Exchange. China Journal of Accounting Research (5) 2012 pg 321-342

[27] Griffin et al (2008) Corporate Governance and Audit Fees : Evidence of Countervailing Relations. Journal of Contemporary Accounting and Economic Vol 4, No 1 (June 2008) pg 18-49

[28] Cohhen \& Hanno (2000) Corporate Governance and The Audit Process. Contemporary Accounting Research 19, 573-594

[29] Y.G Shan et al (2015) An Empirical Comparison of The Effect of XBRL on Audit Fees in The US and Japan. Journal of Contemporary Accounting and Economic 11 pp 89-103

[30] La Rosa dan Caserio (2013) Are Auditors Interested in XBRL? A Qualitative Survey of Big Auditing Firms in Italy. Accounting information systems for Decision Making. Spinger.pp 13-45

[31] Ho \& Hutchinson (2010). Internal Audit Department Characteristic/Activities and Audit Fees : Some Evidence From Hongkong Firms. Journal Of International Accounting, Auditing and Taxation 19.pp 121-136

[32] Low(2004) The Effect of Industry Specialization on Audit Risk Assessments and Audit Planning Decisions. The Accounting Review Vo 79 No 1 (2004)

[33] Tan \& Yim (2014) Can strategic uncertainty help deter tax evasion? Anexperiment on auditing rules, Journal of Economic Psychology 40 (2014) 161-174

[34] Mauludin et al (2002) Income Level and Income Type As Determinants of Tax Return Preparation Fees : An Empirical Investigation. Advance in Accounting Vol 19 pp 189-213

[35] Seetharaman et al (2002) Litigation Risk And Audit Fees : Evidence From UK Firms Cross Listed on US Markets

[36] Gujarati.2009. Basic Econometrics. Mcgraw Hill International Edition

[37] Ghosh \& Tang (2015) Assesing Financial Reporting Quality of Family Firms : The Auditor Persfective. Journal of Accounting and Economic 